\title{
Hermeneutics and community
}

\author{
Milanko Govedarica \\ University of Belgrade \\ 1 Studentski trg, 11000 Belgrade, Serbia
}

\begin{abstract}
The broader meaning of hermeneutics is presented, a meaning that cannot be reduced to the method of scientific research. It is assumed that the basis of hermeneutical rationality is the human way of life, which is characterized not by total self-control, but by a clear interweaving of unconscious and conscious processes. In this context, the thesis that the hermeneutical procedure is inextricably linked with social life, verbal communication, and the cognitive-emotional-volitional receptivity of others is explained. In addition, it is proved that the hermeneutical power of language is the basis of every stable and functional community, and long-term psychosocial integration and coexistence cannot be achieved by the opposite means, that is, through violence.
\end{abstract}

Key words: hermeneutics, community, communication, language, irrationality, integration.

For citation: Govedarica M. 2020. Hermeneutics and community. NOMOTHETIKA: Philosophy. Sociology. Law series. 45 (4): 623-632. DOI 10.18413/2712-746X-2020-45-4-623-632

\section{Герменевтика и общество}

\author{
Миланко Говедарица \\ Университет Белграда \\ Сербия, 11000, Белград, Студенческая площадь, 1
}

\begin{abstract}
Аннотация. Изложен более широкий смысл герменевтики, тот смысл, который не может быть сведен к методу научного исследования. Предполагается, что в основе герменевтической рациональности лежит человеческий образ жизни, который характеризуется не тотальным самоконтролем, а понятным переплетением бессознательных и сознательных процессов. В этом контексте объяснен тезис о том, что герменевтическая процедура неразрывно связана с общественной жизнью, вербальной коммуникацией и когнитивно-эмоциональноволевой восприимчивостью других. Кроме того, доказано, что герменевтическая сила языка представляет собой основу каждой устойчивой и функциональной общины и долгосрочная психосоциальная интеграция и сосуществование не могут быть обеспечены противоположными средствами, то есть посредством насилия.
\end{abstract}

Ключевые слова: герменевтика, сообщество, коммуникация, язык, иррациональность, интеграция.

Для цитирования: Говедарица М. 2020. Герменевтика и общество. NOMOTHETIKA: Философия. Социология. Право. 45 (4): 623-632 (in English). DOI 10.18413/2712-746X-2020-45-4-623-632

\section{Introduction}

In this paper, I will postulate that hermeneutic rationality, as its essential characteristic, includes community life, communicative interaction and relations with other persons. Such a thesis can also be supported by the fact that Dilthey and Gadamer, as significant philosophy founders of hermeneutic method, emphasized intersubjective and dialogical sense of the interpre- 
tation process and understanding historical events and spiritual creations. In their understanding, comprehension comprises the communication of sense, in finding one's own I in some Thou, that is, in the clarification of the given historical and cultural heritage as concrete answers to the questions which the interpreters and authors of that which is interpreted have in common. The point is that hermeneutic research does not represent the application of the method by some neutral research subject to some non-subject object of research, but it is about the relationship between one subject and the other subject, about their co-participation, i.e. about the encompassment of explorers and the explored by a common theme of that which is examined. Accordingly, in the first part of my consideration, I will strive to explain in what sense a joint undertaking or togetherness makes the essential characteristic of hermeneutic rationality.

Among other things, the consideration of the joint character of hermeneutics will include both proving that the rationality of hermeneutic experience arises from interaction with others, and indicating that within hermeneutic way of thinking, a person's freedom is based on unforced communication between I and Thou. In the first case, it is about the fact that other people are our mirror and that precisely that feedback we receive from them, by living together, enables adjusting our arbitrary personal beliefs and attitudes, that is, it provides the possibility for a better or more reliable understanding of one's own and someone else's individual and collective acts. In the second case, it is about the fact that freedom cannot be reduced to individual conquest, something we can and have to obtain by ourselves, but that free personality status also includes its appreciation by communicative partners, some kind of benevolence and generosity on their part. It is precisely the hermeneutic approach in anthropological and sociological thinking that implies giving the other people, the persons whose activities or creations we interpret, the right to manifest their freedom and to be something more than mere objects of research, which means that spirit of togetherness, which is specific to hermeneutic rationality, affirms emancipation in a non-individualistic manner.

On the basis of the previous analyses, in the second part of my consideration, I will endeavor to shed light on the essence of community, what makes a community a community. I will postulate that the relationship between community and hermeneutics is essential in both directions, that is, for both conceptual correlations: it is not only about hermeneutics having a characteristic of togetherness, but also that hermeneutic communication of sense is fundamental to the community. Bearing in mind a possible counterargument that community life contains not only hermeneutic benevolence, understanding and agreements, but also conflicts and misunderstandings, I will pay special attention to the explanation of ambivalent aspects of hermeneutic experience, demonstrating that its essence is not in nonconflicting acceptance of that which is close and understandable to us, but in resolving conflicts, in approaching that which seems strange and irrational to us. In this way, I will strive to prove that hermeneutic character of community is reflected in the skill of living together, which includes the power to turn the absurdity of social life into a communicative sense. Finally, in the conclusion of the paper, I will draw the most important conclusions which arise from the conducted interpretations and analyses.

\section{A shared character of hermeneutics}

If bearing in mind that hermeneutics is the skill of understanding and interpreting, and that every understanding is carried out in some natural language, the language which is spoken and lived in, then it could be said that hermeneutic experience is always intersubjective activity, that it is based on the exchange within a certain community of subjects (persons). In that sense, hermeneutic procedure is always a matter of joint undertaking, even when it unfolds in a complete social isolation and the deepest solitude, since language is what connects us communicatively or mentally with others. Accordingly, Wittgenstein and many other great philosophers thought that a private language was not possible. The point is that linguistic contents that we cannot make comprehensible to others are not comprehensible to ourselves, and vice versa, that signifying material which we 
understand in our own privacy can, in principle, be understood by other people. Admittedly, Wittgenstein was very inspired by Kierkegaard's thinking, which contain a sharp criticism of collectivist generalization and social levelling of personal experiences. However, neither did Kierkegaard deny the significance of community, but he accentuated the primacy of man's interaction with God, in regard to the communication within a group, which means only that the Danish thinker superimposed this kind of togetherness on collective communication, not calling into question the importance of togetherness as such.

In my understanding, a community and communication with the people we are closest to is similar to the community and communication with God, because in both cases, it is about facing linguistic boundaries, something that seems mysterious and inexpressible, but also about linguistic articulation and expressing such experiences. This means that inexpressible is in a certain sense also expressible, because not only can it be shared when meeting face-to-face, but its translation from the sphere of private experiences into the domain of communicable signifying something as vague or irrational is also possible. Although the origin of the language itself is very mysterious, because it concerns precisely the relationship between the human and the divine, it does not, however, reduce the possibility of revealing and announcing that which was hidden and secret through linguistic expressions. Accordingly, it can be said that also those types of hermeneutic experience which could be thought to refute the claim about understanding as a joint or public undertaking, actually confirm that togetherness is at the base of every language and every hermeneutics. A language has different levels, various profound and surface layers, but all of them equally attest to the crucial significance of interaction in a community, for any understanding process or methodical interpretation. In this context, Kierkegaard's criticism of the superficiality of collective communication should be understood as advocating for closer and deeper communication, and not as giving up on community.

It follows from the aforesaid that it is advisable to distinguish between two basic meanings of togetherness: a community in micro and macro formats, that is, (1) the connection that exists between close persons, between I and Thou, and (2) the connection that exists between the members of wider groups and societies. Both types of togetherness are important for the hermeneutical procedure, that is, either type of interaction, which is why the absence of some concrete and obvious form of togetherness in the process of interpretation cannot be an argument against the thesis about the shared character of hermeneutics. As one of the founders of the methodology of spiritual-historical sciences, Dilthey emphasized the significance of autobiographical knowledge for interpreting collective historic events and objectified spiritual acts. This significance implies that correct understanding of one's own individual life, and the individual life entails the interaction with important and close other persons, is a condition for a successful interpretation of social movements. In Dilthey's words, "all the interpretation of written work is only skillful construction of understanding process which spans an entire lifetime and which concerns every type of speech and writing. Therefore, the analysis of understanding presents the foundation for establishing the interpretation rules" [my translation] [Diltaj, 1980: 107]. Human understanding "spans an entire lifetime", because immanent search for interactive and reflexive linguistic sense of that which is occurring is present in every human experience. Therefore, it can be said that, in this sense, a community on the micro-plane has a basic role in the interpretation of global processes in a human society.

Similarly to Kierkegaard, Dilthey could also be thought to have individualized hermeneutic methodology of spiritual and social sciences by his potentiation of the significance of selfawareness, understanding his own personal experience. However, as in the previous case, with this philosopher also, things are not as they seem at first sight. By distinguishing between the explanation process, which is characteristic of natural sciences, and the understanding process, Dilthey points out that: "explanation occurs via exclusively intellectual processes, but we understand by all mental abilities co-participating in the understanding process. In understanding, we start from the context of a whole, which is given to us as live so that we understand the individu- 
al from it" [my translation] [ibid: 69]. The point is that one's own life experience is not something fragmentary or individual, because it actually has a holistic character and is in many aspects more comprehensive than individual subjects of natural sciences. Human personality is a microcosm, and as such it cannot be more comprehensive than the cosmos, but it is a wider unity than natural sciences, than sience of the cosmos, because they are based solely on cognitive acts, while a person's life includes both emotional and volitional processes. Moreover, a human personality can be said to be the god's icon, which certainly elevates it above all the forms of the created nature, and makes its life more complex and richer than other types of natural processes. In this context, Dilthey's insistence on methodological significance of personal experience and autobiographical reflection does not imply individualization, but totalization.

Unlike reductivist and detotalizing cognitive processes inherent in natural sciences, within which a one-dimensional relation between a cognitive subject and a cognitive object is affirmed, it is precisely emotional and volitional acts that imply multidimensional intersubjective communication and the wholeness of living together. It means that a complete coactivity of all mental abilities, which Dilthey ascribed to understanding and hermeneutic process, is not only intrapsychic, but also interpsychic property of the individual who is interpreting, because it always includes interpersonal exchange of psychical experiences. The point is that emotions and will, as complements of cognitive acts which enable proper individual understanding of social-historical processes, are constituted through a community with God and close persons, since emotional and volitional processes concern our receptivity to God, as eminent Other, and meeting or failing to meet the expectations of other people. In this sense, Scheler, one of Dilthey's distinguished disciples, indicated that emotional and volitional attitudes of human person are not something arbitrary and chaotic, but that they represent "the microcosm of the world of values" [my translation] [Šeler, 2011: 103]. Thereby, the author of the book The Human's Place in the Cosmos especially emphasized love as the prime emotion, explaining that through it, that order of values which is not a matter of human creation, but conforming with the hierarchy of goods established by God as the creator of the world, is revealed and crystalized.

In other words, hermeneutic rationality has the property of extended rationality, insofar as, in addition to intellectual, it comprises both emotional and volitional processes, which are of vital importance to the cognition of the wider unity or the so-called life-world, as well as for the coordination with co-participants in life events, that is, for strengthening the order of values on which a community rests. Since a man is a social being, his feelings are always colored by his relationships with his loved ones, and desires and goals of a human individual are mediated by the interests and preoccupations of other people. The idea of extended rationality, in the form of community's insight into mental processes of an individual, is also reflected in hermeneutic potentiation of the inevitable role of pre-judgements in every interpretation process, which Gadamer expecially insisted on. According to his teachings, pre-judgements cannot be reduced to personal idiosyncrasies, to man's misjudgements and arbitrary judgments, because at the base of pre-understanding, there is sociability, intersubjective reality of a human being, without which the understanding process of any text or historical event cannot be started or performed. This philosopher points out that hermeneutics implies "mediating between then and now, between the 'Thou' and the 'I' [Gadamer, 2006: 329], as well as that 'the hermeneutic phenomenon too implies the primacy of dialogue and the structure of question and answer" [ibid: 363]. The point is that understanding and interpreting cannot be successful if interpreters regard the events and texts they interpret as some neutral objects of study, as the topics that do not concern them personally. On the contrary, interpretative progress can be made only when an active relationship is established with the interpreted contents, when one experiences the involvement of one's own subjectivity in the context of research, i.e. when one feels personally involved in shared tasks, questions and answers that are being considered.

As I pointed out in one of the previous studies "hermeneutic skill concerns understanding spoken or natural language, which in its precision cannot be compared to the formal language of 
natural-mathematical sciences, but this shortcoming of its is compensated by mediated forms of communication, through appropriate forms of social life“ [my translation] [Govedarica, 2013: 73]. Habermas's teaching about the indivisibility of hermeneutics from everyday interaction is considered in this study, according to which "ordinary language does not obey the syntax of a pure language. It becomes complete only when enmeshed with interactions and corporeal forms of expression." [Habermas, 1972: 168]. It is about the fact that the imperfection of everyday speech, fragmentarity and susceptibility to chance, do not diminish its truthfulness and rationality, but they provide it differently, i.e. by other means relative to natural-scientific adequate corresponding of the statement with the state of things in the outside world. Ultimately, the truthfulness of theories in the domain of hermeneutic sciences does not concern their accuracy regarding overlapping with objective reality, the reality of the outside objects, but their intersubjective validity, correspondence with intersubjective reality. It is precisely in that sense that the validity of hermeneutic knowledge is inseparable from valid communication in spoken language, which includes accepting and sharing the same values, as well as emotional exchange, that is, "reading" bodily expressions of emotional states of partners in a communication.

Altough the essence of hermeneutic rationality does not consist of conformity, it can be said to possess the characteristic of intersubjective harmonization, i.e. the harmonization between I and Thou. On one hand, it is about the fact that diversity aHd tolerance of a different opinion are much more present in it than in mathematical or natural-scientific forms of cognition, which are not characterized by dialogical divergence, but monological convergence, that is, searching for logically necessary consequences or for true causal-consequential relationships. On the other hand, it is about the fact that relativist approval of arbitrariness, monadic autism or the right to individual idiosyncracies are not characteristic of hermeneutic rationality, but shared examination of realism in the form of mutual understanding of any subjective experience. Hermeneutic cognition equally concerns understanding others and understanding yourself, because it is based on what Habermas calls communicative action, which includes mutual knowing, recognizing and acknowledging other's and one's own experiences. The point is that man's selfunderstanding is mediated by the understanding of others, more precisely, how a concrete person is understood by other people and how he understands other persons. The incapability of understanding by others, the absence of communication with them, is also always followed by the lack of self-understanding, misunderstanding with yourself, the same as the interpretative recognition of own supressed experiences, in the interpreted contents of someone else's experience, is a strong impulse for their self-consciousness and acceptance as a part of one's own personality.

In other words, honest self-reflection and rational consideration of one's own life is achieved only through reflection in the form of receiving feedback information from other people, by reflecting in their eyes and linguistic reactions, because only through them it is possible to correct wrong and reinforce justified beliefs about yourself. The rationality of self-reflection consists of coactivity of all mental processes, of inner coherence and achieving harmony with yourself, but since emotional and volitional acts interfere with what other persons experience and do, the inner harmony cannot be achieved without harmonic interpersonal communication and proper social coordination. Perfecting hermeneutic competencies is in the function of improving communication and coordination with others, and thereby with oneself. Rationality of rich hermeneutic experience consists of precisely enabling deeper understanding of other's experiences, which also results in better communication with one's own person. Therefore, rationality of hermeneutics is communicative rationality, which comprises the capacity for unforced resolution of inner and outer conflicts.

When we interpret other's experiences and actions, then we engage in an equal dialogue with their participants, in the sense that we, in our thoughts or in direct communication with them, acknowledge that they adopted a rational position in the given events and that they knew what they were doing, the same as they to us, tacitly or explicitly, trust that we can understand them in a competent manner. In this context, understanding always includes mutual acceptance 
and approval, which is obvious in an active dialogue, but it is implicitly present in what we can call a hermeneutic dialogue between an interpreter and the interpreted. If we bear in mind the cases of successful active dialogue, then we possess the reasons to assert that mutual understanding implies calling upon the freedom of the other, that is, mutual liberating and encouraging one to be a person, i.e. to rise above the objective state of things. Thereby, the effect of such liberation is much greater than a panful struggle to gain one's freedom, through unilateral imposition of one's own individual attitude, which implies that, besides rational life, unforced emancipation is also a matter of dialogical action and hermeneutic togetherness.

\section{Hermeneutic character of community}

To the extent that a community is not a mere sum of its members, accidental, anonymous and replacable, it is justified to say that hermeneutics, as mutual understanding, is at the core of togetherness. Actually, when the community becomes only a mere collection of individuals it comprises, although they do not know nor understand each other, then the togetherness is in crisis, and is close to dissolution. On the other hand, what makes a community vital and authentic is intensive communication and coordinated cooperation between its members, which comprises hermeneutic capacity of familiarizing with the experiences of strangers, with something previously experienced as someone else's. Thereby, essential or authentic togetherness implies the commitment to the same values, co-participation in their realization, but also the irreplaceable role of every person in this process, that is, mutual awareness and interdependence of people in contributing to the fulfilment of mutual tasks. In that sense, a community is in its essence characterized by both generality, and particularity and personalization, because, on one side, it is characterized by openness to something that exceeds concrete human individuals individually, while, on the other hand, it is precisely characterized by personal concretizations of participating in general or universal values, i.e. particular participation in great causes which congregate its members.

It is important to point out that the highest values, on which human communities rest, are not something self-understandable, so in relation to them too, a hermeneutic approach is necessary. Awareness of this need is thereby greater if bearing in mind that such values are not human creations, but that they have supra-anthropological character. The point is that the values created by man, such as various material goods or culture industry products, do not take the highest positions on the axiological scales, because they are reserved for spiritual and sacred values, the values that human beings can serve and in which they can participate, but which they cannot create, neither individually, nor collectively, because their origin is divine. The aforementioned Scheler's thought about the order of values as a God-given hierarchy of the worthiness of love, implies that humans cannot succeed in their endeavours to invert the divine order, to create higher values out of the lower ones in a sustainable manner, indicating that the most rational thing is to fit into a God-given axiological hierarchy, that is, submit and serve the unchanged value relations. Such a state of things imposes the idea that neither is the authentic human community a human creation, since at the base of human togetherness, there is the providing for the values which exceed the domain of man's free and creative choices. Certainly, there are also non-authentic human communities, such as totalitarian regimes, where social life is established to serve autocratic government instead of serving divine values. However, such communities cannot last long, precisely because they are non-authentic and destructive, so their temporary existence cannot be an argument against the thesis that a true and sustainable togetherness does not have anthropological, but theological foundations.

It is certainly no coincidence that the whole hermeneutics originated from theological hermeneutics, from the interpretation of God's words and acts. However, the term for this discipline has in its root the name of Hermes, a deity from Greek mythology, who was a herald and a mediator between the other gods and humans according to the legend, and who possessed the 
ability to make previously incomprehensible god's will comprehensible to man. Since essential togetherness rests on the commitment to the God-given order of values, it can be said that it is precisely theological hermeneutics that is crucial for understanding the spirit of togetherness. Thereby, it should be borne in mind that theological hermeneutics attests to the possibility of rational confrontation with the greatest (God's) secrets, that is, the interpretative capability for their conception, in such a way that they, instead of being paralysing impediments, become a driving force for spiritual and the entire development of life, of both individual humans, and every concrete human community. In that sense, it can be said that every form of public life has some deep secret at its roots, which means that what is public and what is secret do not exclude each other, but they complement and empower each other, and all thanks to the transformation of Hermes' ability into human hermeneutic capacities. In any case, hermeneutic roots of a community imply the internal ambivalences of human experience, but also the capability of dealing successfully with them, and the significance of such dynamics is the reason why further in the considerations, I will focus on examining those characteristics of hermeneutics, which are at the same time the characteristics of sustainable life together.

As was already pointed out, hermeneutics implies overcoming the contrasts between rationality and irrationality, that is, the extended rationality with the contents which previously seemed completely dissonant and incompatible with it. If in addition to theological exegesis, we also bear in mind psychoanalytic hermeneutics, then it can be asserted that the essence of interpretative progress in understanding consists of turning the unconscious into the conscious, and that which is mysterious and dark into clear and bright, i.e. finding sense in what appears to be senseless. In psychoanalytical understanding, man's psychophysical health, his optimal functioning in private life, professional activities and broader social relations depends crucially on such expansion of consciousness, so Freud's followers paid special attention to the interpretation of dreams and other mysterious expressions of human enigmatic or unconscious experiences. Thus, Lacan emphasizes the significance of interpretative translation of a non-transparent and symptomatic language, the language composed of indirect signs, which can be less or more successful in discreet broadcast of important, personal messages, pointing out that such signifying material, to the extent in which it is successful, also contains within itself creative potential of metaphoricity, since "metaphor is situated at the precise point at which meaning is produced in nonmeaning" [Lacan, 2006: 423]. In my understanding, the point is that both metaphors and psychoneurotic symptoms require interpretation, except in the first case, there is immanent author's autointerpretation of metaphorical expressions, which also considerably facilitates its comprehension in large-scale communication, while the incapability of self-understanding and the necessity of outside interpretation are characteristic of the cases of the mentioned symptomatic creations, i.e. expert interpretation by other subjects. Their shared point concerns the fact that senselessness cannot be turned into sense without successfully performed hermeneutic process, on yourself and/or on somebody else.

The logic of internal, intrapsychic, conflicts and their overcoming is very similar, if not identical, to the logic of the external, social conflicts and their successful resolution, because in both cases, the language has the first and the final word, that is, linguistic processing of the given experience in the form of its communication, excommunication and re-communication. The point is that psychical and social irrationality equally have the form of unintelligible nonintegratedness and disconnectedness, i.e. separation and insubordination of one segment in relation to the other parts and the wider unity which the rogue instance belongs to, which causes unconscious or conscious tension and conflicts between the majority and the minority side of the psychosocial system. By contrast, acquiring rationality in both cases includes understandable integration and the reconciliation of antagonistic forces, that is, providing a functional coordination and coexistence between adequate subsystems within the main system. Nevertheless, hermeneutic (non power of language has a crucial role, both in conflct-emergence phase, and in the process of its escalation or its successful resolution, whether it is about the occurrences in person's 
inner life, or it is about the occurrences in human relationships within a community. In my opinion, such linguistic state of things, the fact that (dis) functional language has equally relevant psychical and social role, attests to subjectivity being inseparable from intersubjectivity, in the sense that intersubjectivity is, at least implicitly, characteristic of every linguistic autointerpretative expression of experiences, as well as every external interpretation of it, hermeneutic-linguistic understanding, regardless of the extent of the privacy in which these processes take place.

Language manifests its power or functionality when understanding, communication and overcoming misunderstandings is achieved through linguistic acts, and its non-power or dysfunctionality is present in the opposite cases. For example, metaphorical expressions are linguistic acts that enable life-saving integration and comprehensible reconciliation of previously disharmonic or chaotic elements of their creators' own experience, while symptomatic language creations are the places where the non-power of such self-integration and self-understanding manifests in their emittents. In a certain sense, it can be said that metaphors are successful symptoms, i.e. the symptoms of internal conflict, which is spontaneously overcome, and also that symptoms are unsuccessful metaphors, that is, attempts of inner reconciliation, which are not fruitful. Although these examples concern psychical processes and the domains of personal experiences, the linguistic dynamics in a social sphere has the identical properties, that dynamics on which a harmonious or non-harmonious life in a community rests, in any part of it. Just as the inner life of any human person is not always harmonious and conflict-free, but thanks to successful language acts, it can always achieve life-saving integration, neither can social life take place without tension and conflict, but fruitful linguistic breakthroughs in overcoming irrational conflicts can also be achieved in the community, in the form of creative social metaphors, and in the direction of achieving a new understanding harmony. Similarly to the cases of psychological disharmony, which cannot be overcome by auto-interpretative language acts, and the local blocks in social communication, where the symptoms of social pathology are manifested, it has to be intervened from the outside, but it is important that heremenutic power of language has the final say in that intervention, and not the forceful means of physical coercion, because it is the only way to achieve a long-lasting reconciliation of conflicting sides.

In accordance with the previously stated, advocating the thesis that every authentic, harmonious and sustainable community rests on hermeneutic power of communication does not imply any naivety, any unfounded belief that one can live in any community conflict-free, and in the manner of direct agreement or uninterrupted tolerant understanding. Oscillations in a social life are inevitable, so hermeneutic understanding in this context, like in individual-psychological domain, cannot be some static attitude of a distant, calm and undisturbed human mind, but it has to have the characteristics of dynamic and ambivalent process of mutual compliance, which includes occasional acute crises and strong turbulences, that is, the episodes of misunderstanding, strife and intolerance. The analogy with psychological conflicts attests to the fact that the conflicts in a community can also be successfully overcome, ultimately, only through linguistic acts as the most important means of the hermeneutic process, at times spontaneously and without external meditation, and sometimes with the inevitable outside interference and adequate expert mediation. However, in both cases, intersubjective confrontation with a kind of distress and the experience of pain is inevitable, that is, with the irrational and/or pathological behaviour, and the difference between milder and more severe forms of social disintegration concerns the degree of acuteness of life troubles and the extent of (auto) destructiveness. In accordance with this degree and extent, the hermeneutic language capacity for social re-integration is more or less manifested, whereby that measure and concrete linguistic effects overcome human will, i.e. crucially depend on mysterious God's will and on human submitting to the God-given order of values.

Despite the fact that it was pointed here to the internal ambivalences of the process of understanding and language articulation, someone might feel that hermeneutic rationality is something too moderate and neutral to be justifiable to assert that a community rests on it precisely. In Bataille's understanding, the downside of rationality consists of the tendency toward conserva- 
tism and self-sufficiency characteristic of it, in the fact that a rational man rejects the "desire to exceed limits - limits that don't simply mark off the individual's margins, but those of reason itself" [my translation] [Bataj, 1988: 152]. Accordingly, in his interpretation of such ideas, Habermas, a big supporter of hermeneutic rationality and consensuality, pointed out that the supreme value in this French author is "conceived of as the other of reason" [Habermas, 1998: 229]. Bataille's thinking is so much more challenging relative to the thesis advocated in this paper, if it is borne in mind that he explained erotic communication, an undoubtedly important and one of the most intensive form of togetherness, as the experience of shared overcoming of individual discontinuity, indicating that its integrative power is based on senseless harm and violently overstepping the boundaries. In my opinion, such differences in thinking are not irreconcilable, because in them, various phases of the same process, initial and mature modality of living together is observed, i.e. the manner in which a community is initiated, on one hand, and the manner in which its successful maintenance is provided, on the other hand. In that sense, I believe it to be true that building close relationships and starting life together - and not only in the erotic aspect, but also in the broader social context - includes the elements of violence and unreasonable overstepping the established boundaries, but I am convinced that an even bigger or more important truth is that the survival and harmonious functioning of every community rests on a dynamic process of mutual understanding, as well as on a necessary regard of reasonable restrictions by its members.

So, a hermeneutic process should not be understood as a straight-line maintenance of rationality, but as a winding path which contains many stages of unreasonableness, but also includes the capacity for their subsequent life-saving understanding. Furthermore, hermeneutic rationality should not be thought of as a technique over which man does not have total control, but as a linguistic power which can only partially be controlled through human will, because its foundation is divine, so many things relating to it seem inexplicable and surprising. If heremeneutics is understood in this way, it is justified to claim that it represents the foundation of every human community.

\section{Conclusion}

Hermeneutics cannot be reduced to a mere method of scientific or philosophical knowledge, because it is not only a collection of rules for the successful interpretation of texts or historic events, but, there is a human way of life at its base, that is, understanding treatment of reality. The point is that unlike animals, which just live, i.e. follow their instincts in the conditions of a given environment, a man lives his life, and that means that he lives in a hermeneutic manner, by consciously directing his own actions toward the realization of certain goals, in accordance with his understanding of the world and the order of values. So, hermeneutics primarily concerns man's living his own life, which implies a certain level of rational self-control, but not total rationality or control over himself, because man is at the same time also guided by God's will, so he is always in the situation to look for hidden rational meaning in something he does not completely control through his interpretations, and which often seems to him irrational or absurd.

God's will is manifested through social interaction, through what the other people say and do, because it is something that exceeds our individual self-control and self-sufficient manner of living one's own life, which is why it is justified to assert that communication in a community is of constitutional significance for hermeneutics. In that sense, in this paper, I have advocated the thesis of the shared character of a hermeneutic process, that hermeneutic act is never an individual interpretation or an individual's private matter, but living a life and interpreting in the spirit of communicative rationality, i.e. in the spirit of cognitive processes which are sensitive to other people and God as eminent Other. It is about hermeneutics, unlike explanation processes in the so-called strict sciences, including the coactivity of cognitive, emotional and volitional processes, their intrapersonal and interpersonal coordination, which affirms dialogical diversity, but also enables sensitive and motivational compliance with the God-given order of values. 
In accordance with the previously stated, I have also defended the thesis of the hermeneutic character of a community in the paper, how sustainable life in every community rests on hermeneutic-linguistic capacities to overcome past misunderstandings, irrational disintegration and conflicts through new and better understanding. It is true that violence in social relations can be effective short-term, concerning indisputable initial significance of violently overstepping the boundaries for starting shared experiences. However, the most important point concerns the fact that the duration of living together is conditioned by the possibility to always repeatedly deal with the ambivalent (divine-human and unconscious-conscious) aspects of hermeneutic rationality through semi-controlled (partially controlled, and partially uncontrolled) language articulation.

\section{References}

1. Bataj Žorž. 1988. O Ničeu, KZNS, Novi Sad,

2. Diltaj Vilhelm. 1980. Zasnivanje duhovnih nauka, Prosveta, Beograd,

3. Gadamer Hans-Georg. 2006. Thruth and Method, Continuum, London, New York.

4. Govedarica Milanko. 2013. Filozofija psihoanalize, SFD, Beograd,

5. Habermas Jurgen. 1972. Knowledge and Human Interests, Bacon Press, Boston.

6. Habermas Jurgen. 1998. The Philosophical Discourse of Modernity, Polity Press, Cambridge.

7. Lacan Jacques. 2006. Ecrits. W.W. Norton \& Company, New York, London.

8. Šeler Maks. 2011. Eseji iz fenomenološke antropologije, Fedon, Beograd.

\section{ИНФОРМАЦИЯ ОБ АВТОРЕ}

Миланко Говедарица, $\mathrm{PhD}$, профессор факультета философии Белградского университетета, Белград, Сербия
INFORMATION ABOUT THE AUTHOR

Milanko Govedarica, PhD, Professor Faculty of philosophy in Belgrade, Belgrade, Serbia 